\title{
The effects of methane seepage at an intertidal/shallow subtidal site on the shore of the Kattegat, Vendsyssel, Denmark
}

\author{
P. R. DANDO, P. JENSEN, S. C. M. O'HARA, S. J. NIVEN, R. SCHMALJOHANN, U. SCHUSTER \& L. J. \\ TAYLOR
}

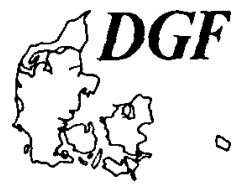

\begin{abstract}
Dando, P. R., Jensen, P., O’Hara, S. C. M., Niven, S. J., Schmaljohann, R., Schuster, U. \& Taylor, L. J.: The effect of methane seepage at an intertidal/shallow subtidal site on the shore of the Kattegat, Vendsyssel, Denmark. Bulletin of the Geological Society of Denmark, Vol. 41, pp. 65-79. Copenhagen, 1994-03-30. https://doi.org/10.37570/bgsd-1995-41-07
\end{abstract}

\begin{abstract}
The effects of methane gas seepage were studied at an intertidal/shallow subtidal site on the Kattegat coast of Denmark. A $30 \mathrm{~m}$ wide zone, containing approximately 65 gas seeps, extended over $70 \mathrm{~m}$ seawards from the shore. This was characterised by the presence of slabs, pavement and small pillars of carbonate-cemented sandstone which formed a partially buried reef. The escaping gas contained 91-100\% methane with some carbon dioxide, 0.6-0.9\%, and hydrogen sulphide. The hydrogen sulphide concentration varied over time and between individual seeps. Gas flow rates of individual seeps ranged up to $211 \mathrm{~h}^{-1}$ and the estimated total flow was $1101 \mathrm{~h}^{-1}$. Seeps were often stopped by sand movement, but the overall gas flow from the site appeared to be constant. The escaping gas generated an interstitial water circulation and drew overlying seawater into the sediment. Water pumped out by the seeps was enriched in phosphate and ammonia. Sulphate reduction rates in the seep area were 1.1-17.1 m moles sulphate reduced and aerobic methane oxidation rates were $0.2-5.5 \mathrm{~m}$ moles methane consumed $\mathrm{m}^{-2} \mathrm{day}^{-1}$. The composition of the flora and fauna surrounding the seeps was affected by the presence of hard substrate (the cemented sandstone). Epifauna was more abundant in the seep zone than elsewhere, whereas the macrobenthic infauna was reduced in the seep zone, possibly due to the cementation. The sediment was almost devoid of meiobenthic organisms, except nematodes. Nematode species numbers, abundance and biomass were lower at the seeps than 5-20 cm away. The nematode fauna penetrated deeper into the sediment close to the seeps than at the seeps themselves. This is explained by the interstitial water circulation at and close to the seeps. ${ }^{14} \mathrm{C}$ measurements showed that little methane carbon was entering the food web surrounding the seeps.
\end{abstract}

P. R. Dando, S. C. M. O'Hara, S. J. Niven, U. Schuster \& L. J. Taylor, Marine Biological Association of the United Kingdom, Plymouth PLI 2PB, United Kingdom. P. Jensen, Marine Biological Laboratory, University of Copenhagen, Strandpromenaden 5, DK-3000 Helsing $\phi r$, Denmark. R. Schmaljohann, Institut für Meereskunde an der Universität Kiel, Düsternbrooker Weg 20, D-24105 Kiel, Germany. October 20th 1992.

\section{Introduction}

Methane seepage occurs at several sites in the northern Kattegat and Skagerrak along the edge of the Fennoscandinavian border zone. The gas is also known from a number of wells and seeps on land in Vendsyssel, the northern part of Jutland, where bore holes have indicated that it was generated in Eemian and early Weichselian marine deposits up to $200 \mathrm{~m}$ below sea level (Jessen, 1936; Dreyer Jørgensen, 1945; Laier, Jørgensen, Buchardt, Cederberg \& Kuijpers, 1992).

Gas seepage affects the topography of the seafloor and causes sediment sorting and lithification of sediment which, in turn, affects the faunal composition of the area (Dando \& Hovland, 1992). A feature of submarine seepages is the cementation of sediments by methane-derived carbonate. In the Kattegat these are usually lithified sandstones which are exposed by sediment erosion to reveal pavements, individual slabs, vertical pillars and mushroom-shaped structures on the seafloor (Jørgensen, 1992; Jensen, Aagaard, Burke, Dando, Jørgensen, Kuijpers, Laier, O'Hara \& Schmaljohann, 1992). The effects of seepage on the bottom topography, the biota and the sediment geochemistry of offshore sites in the Kattegat have been described recently (Jensen et al. 1992). This paper describes the effects of methane seepage on the 
topography, sediment chemistry and biology at a shallow water, intertidal - low subtidal, site in the northern Kattegat on the Danish coast.

\section{Methods}

Gas flow was measured by trapping the gas with an inverted funnel placed over the seeps and timing the collection of the gas in graduated, inverted, water-filled tubes. Analytical samples of gas were collected in $70 \mathrm{ml}$ inverted glass septum bottles, by displacement of water, and stored after the addition of $2 \mathrm{ml} 2 \% \mathrm{w} / \mathrm{v}$ sodium azide solution. The hydrogen sulphide concentration in the gas was determined by immediately fixing the gas sample by the addition of $2 \mathrm{ml} 2 \% \mathrm{w} / \mathrm{v}$ cadmium chloride solution in May 1992, or 5\% w/v zinc acetate solution in September 1992. Sulphide was determined colorimetrically by the method of Cline (1969). Methane and hydrogen were separated by gas chromatography on a $2.15 \mathrm{~m}$ column of $13 \mathrm{X}$ molecular sieve, using zero-grade nitrogen as carrier. The gases were detected using a Figaro TGS 711 solid-state detector. Methane was additionally measured with a flame-ionization detector. Carbon dioxide was separated by gas chromatography, using zero grade nitrogen as carrier, on a $2 \mathrm{~m}$ long, $2 \mathrm{~mm}$ i.d. column packed with Unibeads A of 80-100 mesh. The carbon dioxide was converted to methane by passing it, together with hydrogen, through a catalytic column of $0.5 \%$ ruthenium on alumina (Johnson Matthey), heated to $300^{\circ} \mathrm{C}$. The methane was measured using a flame-ionization detector. Analytical precision was $\pm 3 \%$ of the reading.

Interstitial water flow around seeps was studied by sampling seeps under calm conditions when covered by 5 $\mathrm{cm}$ or less of water. Interstitial water samples of 0.5 to 1.0 $\mathrm{ml}$ were collected by drawing them through a plastic tube of $1 \mathrm{~mm}$ i.d., plugged with quartz wool at the base, into a syringe. The sample was collected over a period of 30 $60 \mathrm{~s}$.

Seep water was collected by placing a shallow inverted funnel over the seep. At the top of the funnel a Y-fitting was attached which had taps on both arms of the Y. The ends of these arms led into evacuated polythene bags. Water and gas from the seep were collected in one of the bags for sufficient time to allow the initial seawater in the funnel to be washed out. Gas and water were then collected in the second bag. The water was immediately used for analysis after filtering through a glass fibre filter of $0.2 \mu \mathrm{m}$ porosity.

Sediment sampling and chemistry followed previously described methods (Dando, Austen, Burke, Kendall, Kennicutt, Judd, Moore, O'Hara, Schmaljohann \& Southward, 1991). Sediment cores of $15-40 \mathrm{~cm}$ depth were collected by hand in translucent PVC tubes of 55 $\mathrm{mm}$ i.d. Interstitial water was extracted under argon by pressure filtration through a cellulose acetate filter of 0.2 $\mu \mathrm{m}$ porosity. Sulphide, thiosulphate and sulphite were determined by reaction with monobromobimane. The de- rivatives were separated by HPLC and measured by fluorescence (Newton, Dorian \& Fahey 1981). Ammonia was measured by the method of Dal Pont, Hogan \& Newell (1974) and phosphate and nitrite according to Grasshof, Ehrhardt \& Kremling (1983).

Sulphate reduction rates were measured in $4 \mathrm{ml}$ polystyrene syringe sub-core samples. The stoppered syringe cores were injected with $5 \mu \mathrm{l}$ of $\mathrm{K}_{2}{ }^{35} \mathrm{SO}_{4}$ along the centre of the core and incubated in the dark for $12-15 \mathrm{~h}$ at sediment temperature, $13^{\circ} \mathrm{C}$ in October $1990,8^{\circ} \mathrm{C}$ in May 1991 and $15^{\circ} \mathrm{C}$ in May 1992. At the end of the incubation the sediment was extruded into glass vials containing 4 $\mathrm{ml} 5 \%$ neutralised zinc acetate solution. This precipitated any hydrogen sulphide and stopped further bacterial activity. The samples were then frozen until analysis when reduced sulphur species were all converted to hydrogen sulphide by reaction with acidified chromous chloride solution (Zhabina \& Volkov, 1978). The $\mathrm{H}_{2} \mathrm{~S}$ released was trapped in zinc acetate solution, mixed with scintillant (Packard Instagel) and the amount of ${ }^{35} \mathrm{SO}_{4}=$ reduced determined by scintillation counting, using the channel ratios method for quench correction. The radioactivity of the ${ }^{35} \mathrm{SO}_{4}=$ remaining was determined by scintillation counting of sediment washings. Sulphate was determined by ion chromatography (Dando et al. 1991) and the water content of the sediment was measured by drying the sediment to constant weight at $60^{\circ} \mathrm{C}$. Sulphate reduction rates were calculated by multiplying the proportion of the total ${ }^{35} \mathrm{~S}$ reduced by the fractionation factor and by the dissolved sulphate in $1 \mathrm{dm}^{3}$ sediment (Jørgensen, 1978). Rates were integrated over the upper $20 \mathrm{~cm}$ of the sediment column to provide comparisons with other studies.

Potential aerobic methane-oxidation rates were measured by incubating sediment suspensions in seawater under a methane / air gas phase which gave a final concentration in the aqueous phase of $1 \mu \mathrm{M}$ methane. The consumption of methane was followed by gas chromatography. Direct counts of bacterial numbers were made by epifluorescence microscopy of sonicated, diluted sediment samples stained with acridine orange (Meyer-Reil, 1983).

Sediment samples for macrofaunal analyses were collected by pushing a stainless steel box-core liner of 0.085 $\mathrm{m}^{2}$ into the sediment at low water and digging out the contents. The fauna was collected by sieving the sediment through a mesh of $500 \mu \mathrm{m}$ diameter, fixed in buffered $2 \%$ formalin in seawater and transferred to $75 \%$ ethanol. Macrofaunal biomass was calculated as blotted wet weight (ww) of ethanol preserved specimens, excluding bivalve shells. Sediment samples for meiofaunal analyses were collected in May, June and September 1991 with $30 \mathrm{~cm}$ long tubes, $4 \mathrm{~cm}$ in diameter, pushed down to $10-20 \mathrm{~cm}$ depth. Samples were taken over the seeps and at distances of $5 \mathrm{~cm}, 10 \mathrm{~cm}$ and $20 \mathrm{~cm}$ from the seeps; controls were sampled at a site $30 \mathrm{~m}$ north of the seep area. The sediment cores were sliced in $1 \mathrm{~cm}$ horizontal intervals and inspected for "soft meiofauna organisms", i.e. gastrotrichs, gnathostomulids and turbellar- 


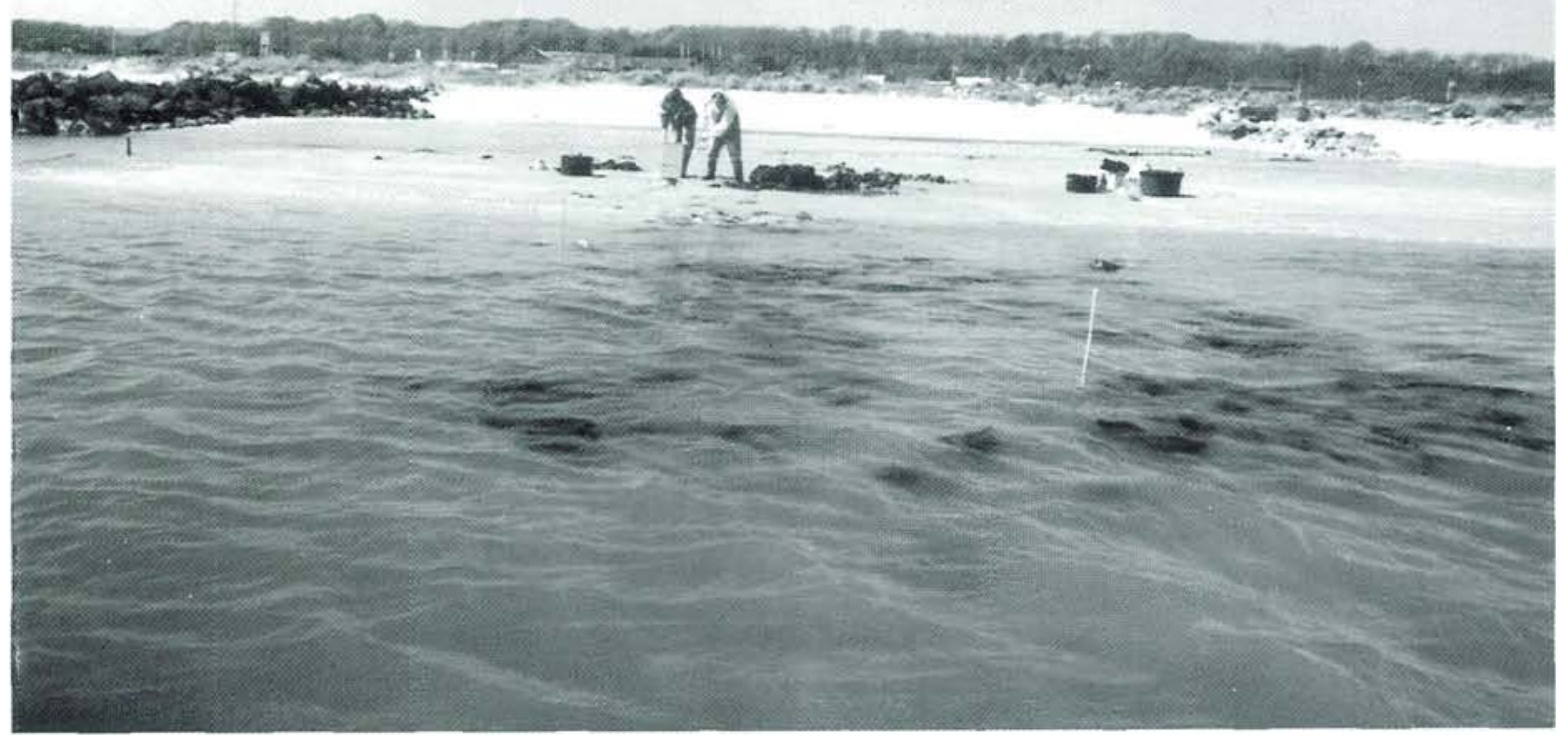

Fig. 1. The seepage site at Bangsbo strand in May 1992, showing the highest part of the reef exposed to the right of the two figures. Submerged algae-covered carbonate-cemented sandstone slabs can be seen in the foreground.

ians. Other samples were fixed in $4 \%$ formalin and stored for later examination for "hard meiofauna organisms", i.e. harpacticoid copepods, kinorhynchs, nematodes, oligochaetes and ostracods. These samples were treated as in Jensen (1983); a sample splitter (Jensen, 1982) was applied when samples contained more than 200 individuals. Trophic classification of the nematodes follows Jensen (1987).

Tissues for ${ }^{14} \mathrm{C}$-measurements were acidified with $5 \mathrm{M}$ $\mathrm{HCl}$ to remove inorganic carbon, washed with distilled, de-ionised water which was passed through a $0.2 \mu \mathrm{m}$ filter, dried at $55^{\circ} \mathrm{C}$ and ground in a small ball mill. Aliquots of the resulting powder were sent to the NERC Radiocarbon Laboratory, East Kilbride, Scotland or the Radiocarbon Accelerator Unit, Oxford University for analysis by scintillation counting or accelerator mass spectrometry respectively.

\section{Results}

\section{Site description}

The area studied at Bangsbostrand (Figs. 1 \& 2) lies $5 \mathrm{~km}$ south of Frederikshavn on the shores of the Kattegat. On the landward side a line of sand dunes separates the sandy beach from arable fields. Seawards the beach is stabilised by $35-40 \mathrm{~m}$ long groynes constructed of boulders. The groynes were built at intervals of approximately $80 \mathrm{~m}$ along the beach. The gas seeps extend in a line running ESE seawards $70 \mathrm{~m}$ from the mean tide level to a large sand wave, and beyond this for at least a further $100 \mathrm{~m}$. The seaward limit is unknown. Inside the sand bar the area of gas seepage has a width of approximately $30 \mathrm{~m}$ (Fig. 2). Within this area there are an average of 65 active gas seeps, some intermittent and others continuous. The area of gas seepage shown in Fig. 2 contains large amounts of carbonate-cemented sediment which forms a partly buried reef. The concreted material is mainly sandstone but mudstone and cemented shell deposits are also present. The carbonate is methane-derived high-magnesium calcite and dolomite as described by Jørgensen (1976, 1992). Over most of the reef the sandstone takes the form of slabs or pavements between 1 and $10 \mathrm{~cm}$ thick but in the deeper part of the area overlying slabs and small pillars are present. Sections of the sandstone reveal that much of it has been exposed, colonised by barnacles, mytilids etc. and eroded before being buried again and subjected to further cementation. Pieces are often retrieved from below the sand with green Enteromorpha attached, indicating recent burial by sand movement.

At the highest point of the reef the sandstone projects

Dando et al.: The effects of methane seepage 


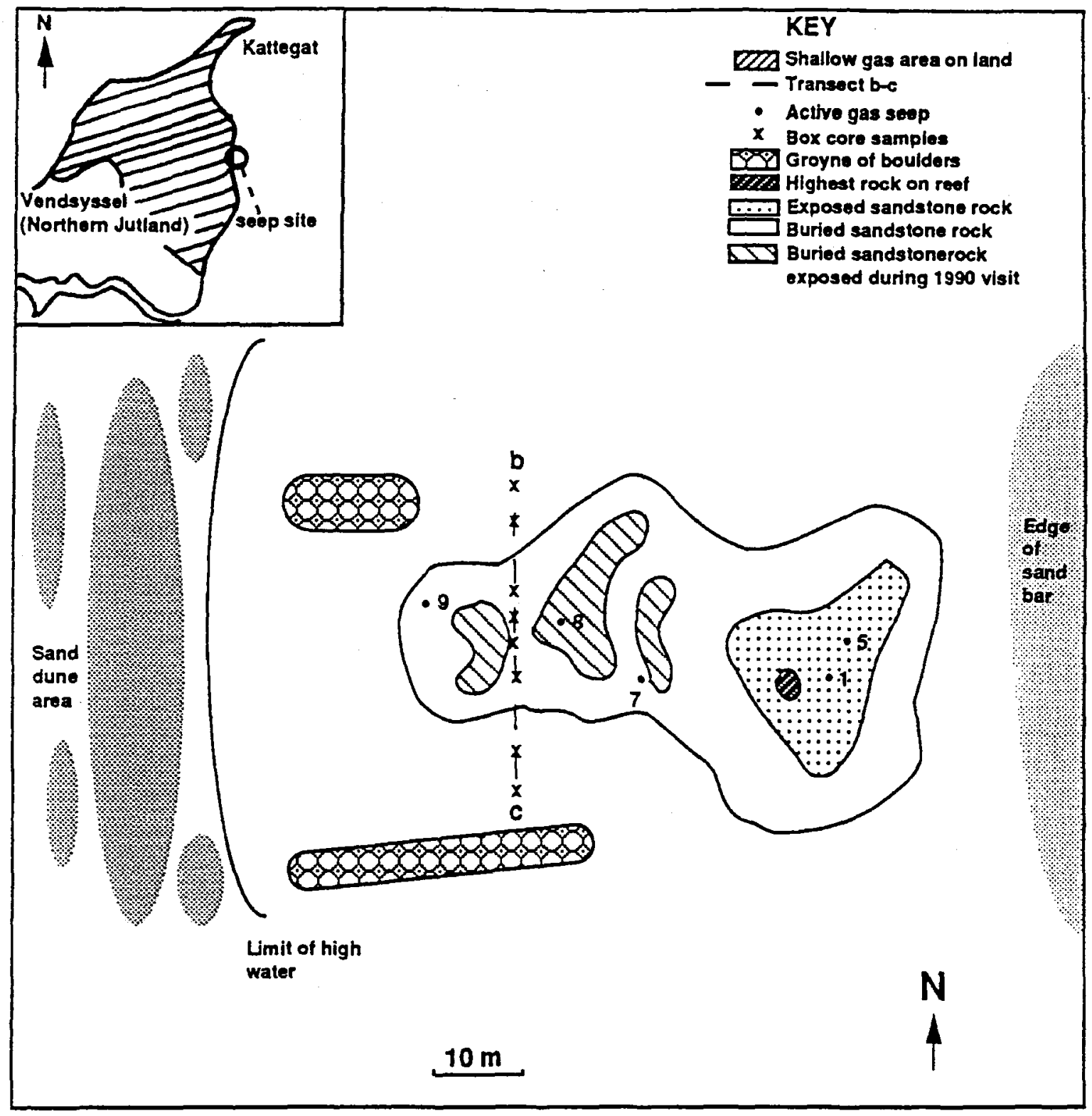

Fig. 2. Location map (inset) and plan of site showing the position of the seeps referred to in the text.

$30 \mathrm{~cm}$ above the surrounding seabed. This area is shown, when exposed at low water, immediately to the right of the figures in Fig. 1. The reef was probably higher since there has been considerable removal of this sandstone for sale to aquarists. Large scale excavation of the reef, using crowbars, was observed during sampling on the site in May 1991 and September 1992. On the latter occasion excavation of the rock was carried out by divers equipped with dry suits and snorkels.

The water depth over the site is controlled largely by wind strength and direction and by the air pressure differ- ential between the North Sea and the Kattegat, since the tidal range has a maximum of only $0.4 \mathrm{~m}$ while water depth can vary by $1.3 \mathrm{~m}$. Under extreme high water conditions the water extends beyond the landward end of the groynes, while under extreme low water conditions the sand bar is exposed (Fig. 2). Salinity changes in the inshore water can be rapid as the mixture between North Sea inflow and Baltic outflow varies: changes between $19.00 \%$ and $31.25 \% 0$ were observed during the study.

Sand waves run parallel to the shore at approximately $50 \mathrm{~m}$ intervals and at times considerable transport of sand Bulletin of the Geological Society of Denmark 

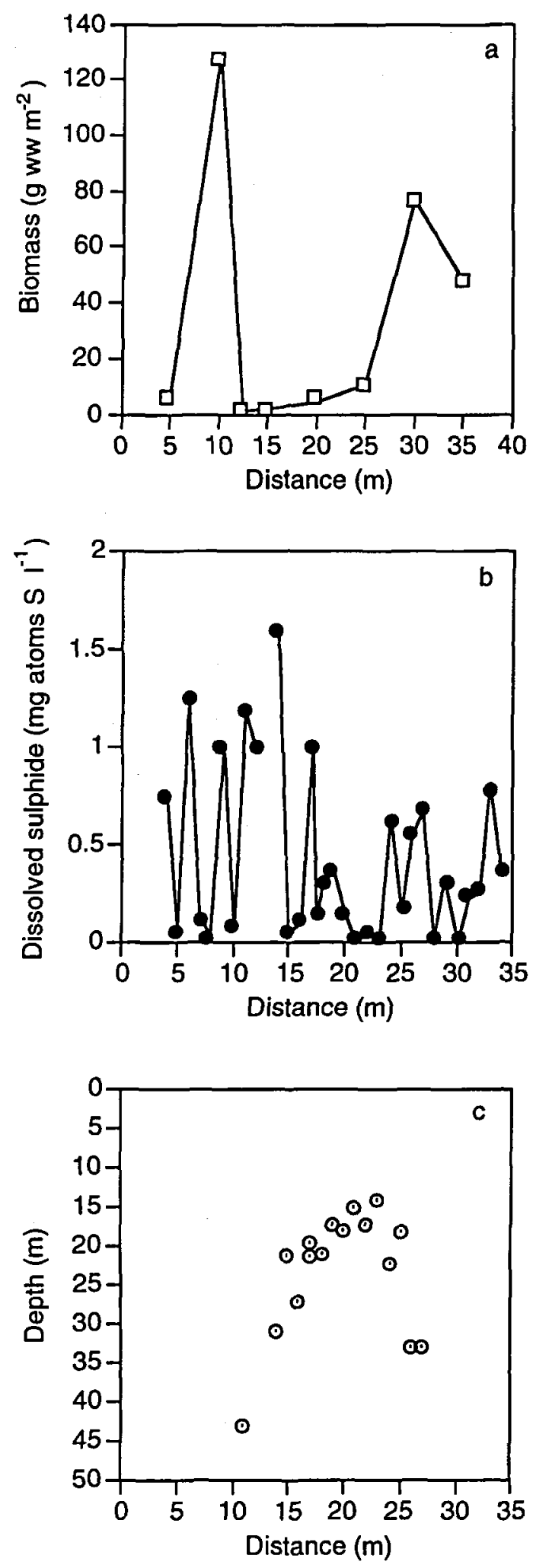

Fig. 3. North - South transect, b-c in fig. 2 , across the reef showing: a. macro-infaunal biomass, b. pore water sulphide concentration at $10 \mathrm{~cm}$ depth, $\mathrm{c}$. sediment depth to the top of the buried sandstone.

Dando et al.: The effects of methane seepage occurs. The carbonate-cemented sandstone pavement shown in Fig. 2 was exposed in October 1990. This area was subsequently observed to be buried in May and September/October 1991. It was re-exposed in April 1992 and buried again in May 1992. A transect across this area (b-c in Fig. 2) was made in September 1992 and is shown in Fig. 3c. The top of the carbonate was buried under $20 \mathrm{~cm}$ of sand at this time. Observations, using marked stakes, showed that the sand above seep 8 increased in depth by $17 \mathrm{~cm}$ during a week, $11 \mathrm{~cm}$ deposi-
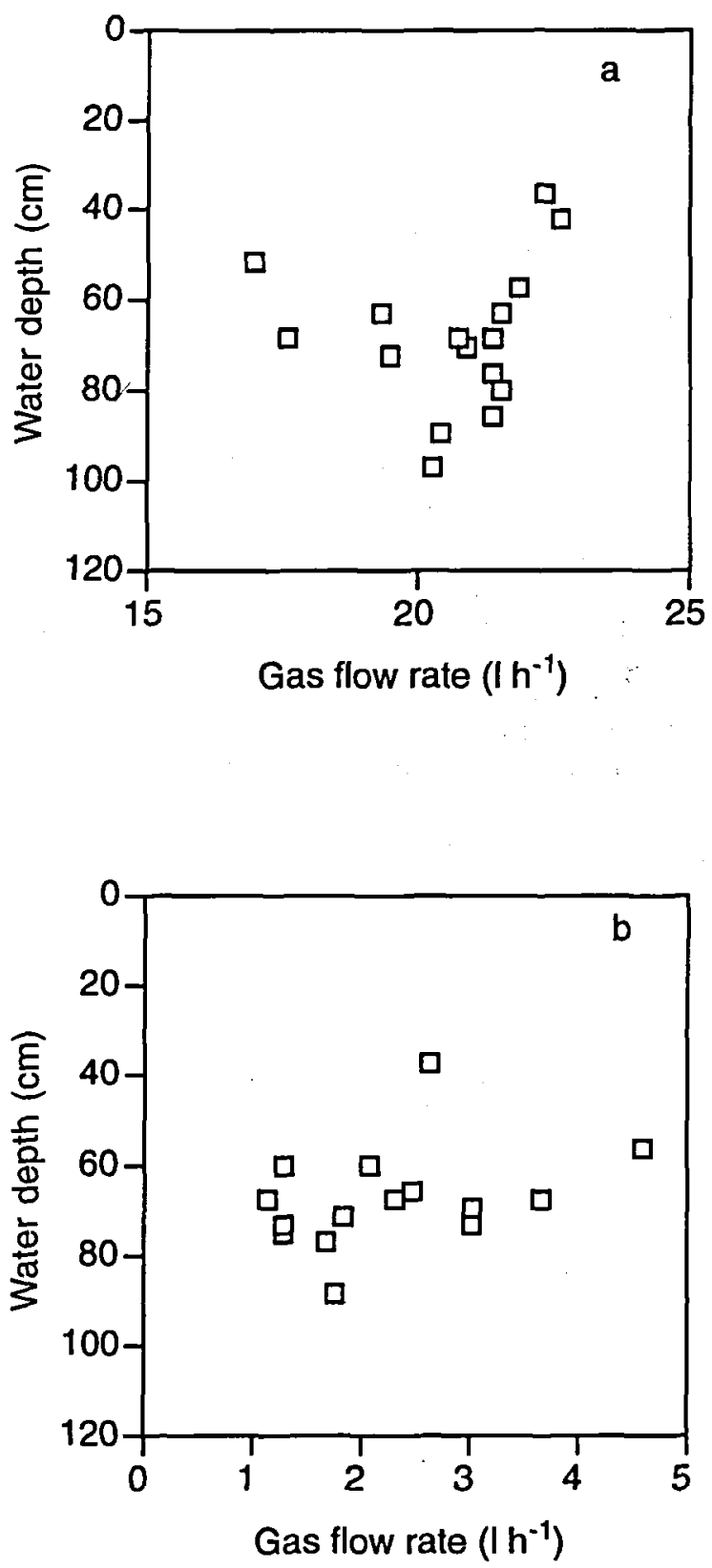

Fig. 4. Variations in gas flow rate with overlying water depth at a. seep 1 and b. seep 5 . 


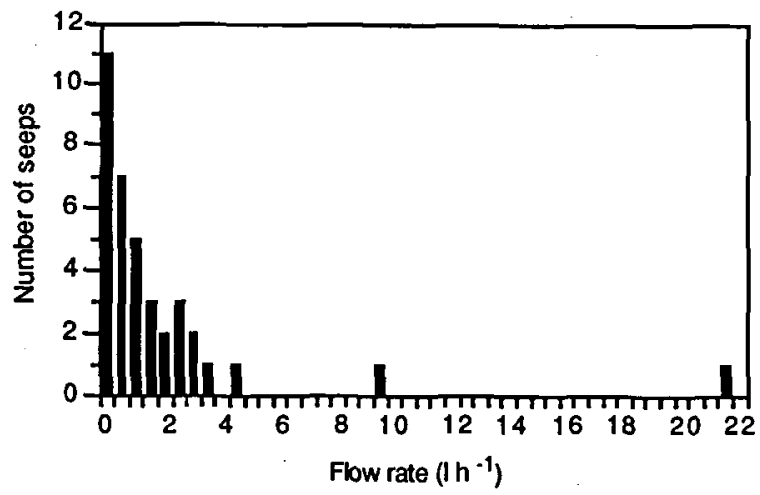

Fig. 5. Histogram showing the number of seeps with particular flow rates.

tion occurred during 1 day. This sand movement can rapidly change the distribution of seeps across the site.

\section{Gas flow and composition}

Gas bubbled out of the seabed through holes in the sandstone and in gaps between the concreted sections of sediment. In places the gas diffused as small bubbles, 'fizzed' out of pores in the sandstone. Often gas bubbled out of the sediment at the base of the sandstone and accumulated under overhangs, from where it was released as large bubbles. It was difficult to obtain sediment core samples from the gas seeps because of the buried cemented sediment. When cores were collected from directly over a seep it was observed that the gas bubbles rose through channels of coarse fill, shell or very coarse sand. These channels meandered through the sediment and were rarely vertical for more than $5-10 \mathrm{~cm}$. Thus the gas channels often passed into and out of the core section several times, resulting in complex geochemical profiles.

In May 1991 over $25 \%$ of the gas flux was observed to come from two seeps, one with a rate of approximately $20 \mathrm{l} \mathrm{h}^{-1}$ (seep 1 in Fig. 2) and the other with a flow of approximately $101 \mathrm{~h}^{-1}$. Seep 1 has a relatively constant flow rate. When measured in September 1992 it appeared, with the exception of four unusually low flow rate measurements, to be controlled by the overlying water depth, being fastest at low water levels (Fig. 4a). Other seeps, such as seep 5, $5 \mathrm{~m}$ NE of seep 1, when measured over the same period, did not appear to be influenced by changing water depth (Fig. $4 \mathrm{~b}$ ). Seep 1 also showed a nearly constant flow rate over the longer term. It had a gas flow rate of $21.80 \pm 1.01$ (S.D.) $\mathrm{l} \mathrm{h}^{-1}$ in May 1991, $20.19 \pm 0.491 \mathrm{~h}^{-1}$ in May 1992 and $20.65 \pm 1.521$ $\mathrm{h}^{-1}$ in September 1992. The remaining seeps had measured flows in the range 0.15 to $5.00 \mathrm{l} \mathrm{h}^{-1}$ (Fig. 5) with mean flow rates of $1.291 \mathrm{~h}^{-1}$ in May $1991,1.20 \mathrm{l} \mathrm{h}^{-1}$ in September 1991 and $1.17 \mathrm{l} \mathrm{h}^{-1}$ in April 1992. Using a mean value of $1.22 \mathrm{l} \mathrm{h}^{-1}$ for the seeps whose flow rates were not measured we may calculate a total gas flux from the site of $1101 \mathrm{~h}^{-1}$. Further details of the variations in flow rate of the gas with time and site conditions are presented elsewhere (Dando, O'Hara, Schuster, Taylor, Clayton, Baylis \& Laier, 1993a).

The methane content of the gas varied between 91 and $100 \%$ in samples measured at intervals between October 1990 and September 1992. During the latter month measurements on 32 samples from 5 seeps gave a mean methane content of $99.41 \pm 0.87 \%$ (S.D.). Most of the residual gas was carbon dioxide, this showed a content of $0.7-0.9 \%$ in 6 samples analysed. Hydrogen concentrations were less than $10 \mathrm{ppm}$ in the seep gas and carbon monoxide could not be detected. Hydrogen sulphide was sometimes absent from the seeps, while on other occasions the whole site smelt strongly of $\mathrm{H}_{2} \mathrm{~S}$ and concentra-
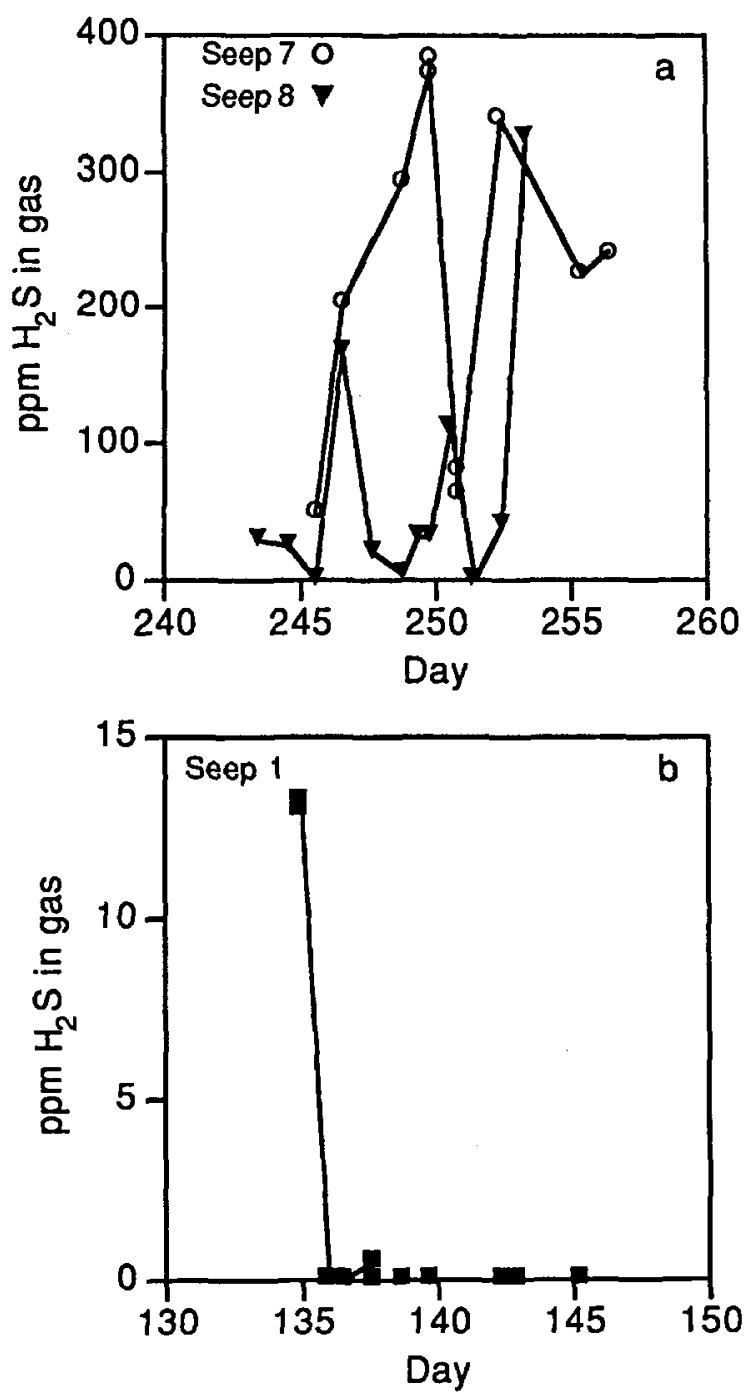

Fig. 6. Variation in hydrogen sulphide content in the seep gas in 1992: a. seeps 7 and 8 , b. seep 1 . 
Table 1. Biological characteristics of the nematode fauna down to $20 \mathrm{~cm}$ sediment depth, at seeps, at distances $5-20 \mathrm{~cm}$ from seeps and at a control site $30 \mathrm{~m}$ north of the seep area. Means, with minimum and maximum values in parenthesis.

\begin{tabular}{lccc}
\hline & seeps & $5-20 \mathrm{~cm}$ & $30 \mathrm{~m}$ \\
\hline $\begin{array}{l}\text { Depth penetration } \\
(\mathrm{cm})\end{array}$ & 5 & 12 & $>20$ \\
Number of species & $(4-6)$ & $(10-18)$ & 29 \\
& 23 & 30 & $(26-32)$ \\
Abundance & $(20-24)$ & 1875 & 1050 \\
$\left(10^{3}\right.$ ind. $\left.\mathrm{m}^{-2}\right)$ & 455 & $(1120-2320)$ & $(980-1400)$ \\
Biomass & $(380-670)$ & 2.7 & 1.2 \\
$\left(\mathrm{~g}\right.$ ww $\left.\mathrm{m}^{-2}\right)$ & 1.2 & $(2.5-3.2)$ & $(0.8-1.5)$ \\
\hline
\end{tabular}

tions of up to $338 \mathrm{ppm}$ were measured in the escaping gas. The shallower seeps had the highest $\mathrm{H}_{2} \mathrm{~S}$ concentration in the gas, but this varied over time (Fig. 6). It is clear from observations on the beach of the strength of the hydrogen sulphide smell from individual seeps, and from the measurements of $\mathrm{H}_{2} \mathrm{~S}$ in the gas of the seeps studied in detail, that hydrogen sulphide issues from different seeps at different times. Fig. 6a illustrates this for two seeps $11 \mathrm{~m}$ apart (7 and 8 in Fig. 2) and Fig. 6b shows the changes in hydrogen sulphide content in the gas from seep 1 .

\section{Flora and fauna}

The most conspicuous aspect of the seep area was the presence of the sandstone reef. Elsewhere on this part of the coast there is little rock except where lines of boulders have been placed to form groynes in order to stabilize the beach. The reef therefore forms a habitat for macroalgae and epifauna which would otherwise not occur on the sandy bottom. Species present include the green algae, Ulva, Monostroma, Cladophora and Enteromorpha spp., mussels, Mytilus edulis, barnacles, Balanus crenatus, and the starfish Asterias rubens. The tube-dwelling polychaete worm, Lanice conchilega, was conspicuous in the seep area but not on other parts of the beach. This was because of the wave action and sand movement so that only worms with tubes attached to the sandstone could survive. The exposed part of the tubes were often seen waving in the stream of gas bubbles issuing from a seep.

Shore crabs, Carcinus maenas, were concentrated around the seeps and often burrowed into the sand directly above a gas outlet. At seep 5 (Fig. 2) which issued from a $5 \mathrm{~cm}$ depression in the sandstone, four crabs were seen, on one occasion, darting in and out of the bubble stream.

Hovland \& Thomsen (1989) have suggested that the high density of macrofauna, largely filter feeders and predators, seen around gas seeps may be indicative of the presence of a food web based on methane oxidising bacteria. This was investigated for the present site by examining the ${ }^{14} \mathrm{C}$ content of tissues from animals living at the seep site. The methane escaping from the Bangsbostrand site contains almost no detectable ${ }^{14} \mathrm{C}$ (Dando et al. 1993a) and therefore depletion of ${ }^{14} \mathrm{C}$ in the animal tissues would indicate the presence of methane derived carbon in the animal. The major biomass of macrofauna close to the seeps was the filter feeding bivalve mollusc Mytilus edulis and the crab Carcinus maenas. Other animals were not present in sufficient numbers to provide sufficient carbon for dating. If a substantial production of carbon by methane-oxidising bacteria is entering the food chain via protozoa and other bacteriovores then animals living in the vicinity should show some old carbon in their tissues. M. edulis is known to feed to some extent on bacteria. $\mathrm{A}{ }^{14} \mathrm{C}$ measurement on non-gut tissues from one of the $C$. maenas living directly above a gas outlet gave an activity of $115.4 \%$ modern $(1956=100 \%)$, compared with no ${ }^{14} \mathrm{C}$ in the escaping methane. This ${ }^{14} \mathrm{C}$ value for the crab was in the range expected for a shallow water marine animal living in a photosynthesis-based food web and indicates that there was no significant methane carbon input into the crab tissues.

Similar results were obtained for the mussel, Mytilus edulis. Specimens of the mussel living on sandstone above a seep, and subjected to a continual stream of gas bubbles, had a ${ }^{14} \mathrm{C}$ content for their non-digestive tissues of $115.1-115.6 \%$ modern compared to $116.9-117.6 \%$ modern for mussels living on a groyne $700 \mathrm{~m}$ from the seep site. The slight reduction in ${ }^{14} \mathrm{C}$ in the animals from the seep site suggests a maximal contribution of $1-2 \%$ methane carbon to the tissue carbon of the mussels.

Sediment infauna were found to be reduced in the number of individuals and species close to the seeps. Box core samples were taken along the transect b-c (Fig. 2). The biomass of the macrofauna in the samples (blotted wet weight of ethanol-preserved specimens, excluding bivalve shell) is shown in Fig. 3a. Four samples from sediment above the buried reef had a sample biomass of $0.41 \pm 0.35 \mathrm{~g}$, whereas the four samples outside the reef area had a sample biomass of $5.47 \pm 4.4 \mathrm{~g}$. The major difference in biomass was due to the presence of the lugworm, Arenicola marina, in samples away from the reef. A similar difference in biomass of the macro-infauna between the seep area and non-seep area samples (not shown) was observed on a transect of box cores taken across the seep area $27 \mathrm{~m}$ east of b-c.

The dissolved sulphide content of the interstitial water, 


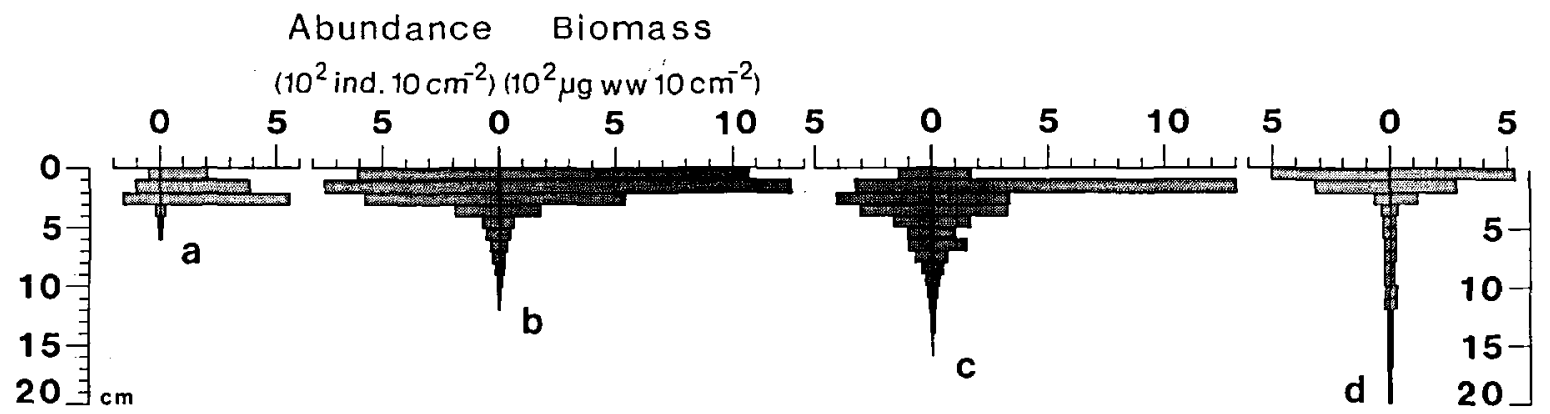

Fig. 7. Vertical distribution of nematode abundance and biomass from: a. the seep, b. $5 \mathrm{~cm}$ from the seep, c. $10 \mathrm{~cm}$ from the seep, d. a control site $30 \mathrm{~m}$ north of the seep.

along the transect $\mathrm{b}-\mathrm{c}$, at a sediment depth of $10 \mathrm{~cm}$ is shown in Fig. 3b. There was a concentration range from zero to $1.6 \mathrm{mM}$, with no clear pattern except that the more extreme values were found to the north of the buried reef and low concentrations were observed where the sandstone was closest to the sediment surface. The concentrations at the positions where the four reef box core samples were taken were in the range $0.05-0.16 \mathrm{mM}$ and at the positions of the four off-reef box cores were zero to $0.09 \mathrm{mM}$. In both cases the box core with the highest biomass of macro-infauna also showed the highest hydrogen sulphide concentration.

Gnathostomulids, harpacticoid copepods, kinorhynchs, oligochaetes and ostracods were rarely found in any of the samples. The abundance of gastrotrichs and turbellarians was found to be low, less than 1 individual $\mathrm{cm}^{-2}$. Nematodes were the only taxon occurring in sufficient numbers to be studied quantitatively (Table 1). In total, 42 nematode species were found. Typical thiobiotic species, i.e. very long and slender animals (Leptonemella aphanothecae, Sabatieria longispinosa, species of
Eleutherolaimus sp. and Paralinhomoeus sp.) were absent in the seep cores, but were present in all the other samples. There were major differences between the nematode fauna at the seeps, close to the seeps $(5-20 \mathrm{~cm})$ and at the control site in terms of depth penetration, number of species and abundance (Table 1, Fig. 7). Biomass values were highest close to the seeps $(2.7 \mathrm{~g} \mathrm{ww}$ $\mathrm{m}^{-2}$ ), whereas biomass values from the seeps and the control site were almost the same $\left(1.2 \mathrm{~g} \mathrm{ww} \mathrm{m}^{-2}\right)$. The relative proportions, in abundance, of microbial feeders, predators and omnivores between the nematode fauna from seeps, close to the seeps and from the control site were found to be almost identical. Microbial feeders were found to be the dominant group of nematode present, between $79 \%$ and $82 \%$. The proportion of predators varied between $13 \%$ and $16 \%$, whilst omnivores constituted only $5 \%$ of the fauna. Microbial feeders were dominated by Sigmophoranema rufum, Daptonema normandicum and Dichromadora hyalocheile. Only four predatory species were found; Enoplolaimoides brunetti, Enoplolaimus litoralis, E. propinquus and Chaetonema riemannii, of
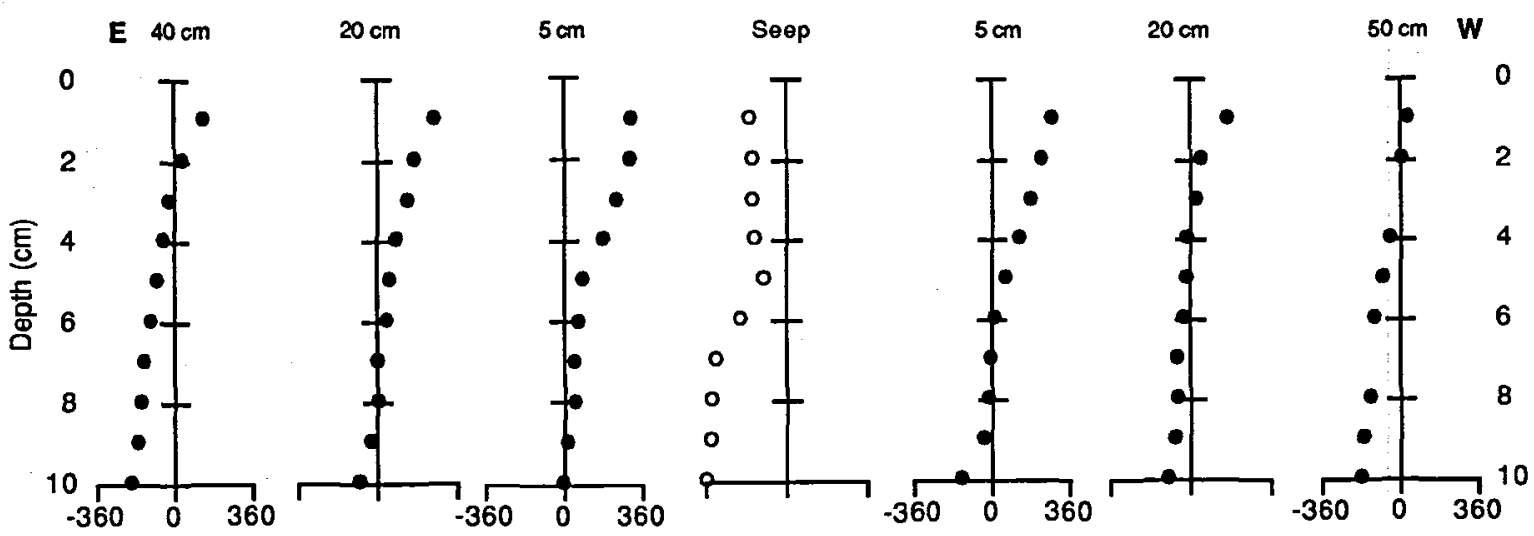

m V

Fig. 8. Sediment redox profiles at different distances from seep 9. 
Fig. 9. Methane concentration $\mathrm{O}-\mathrm{O}$ and aerobic methane oxidation rate profiles along a seaward - landward transect through a seep. Measurements were made in samples taken from the upper $4 \mathrm{~cm}$ of sediment.

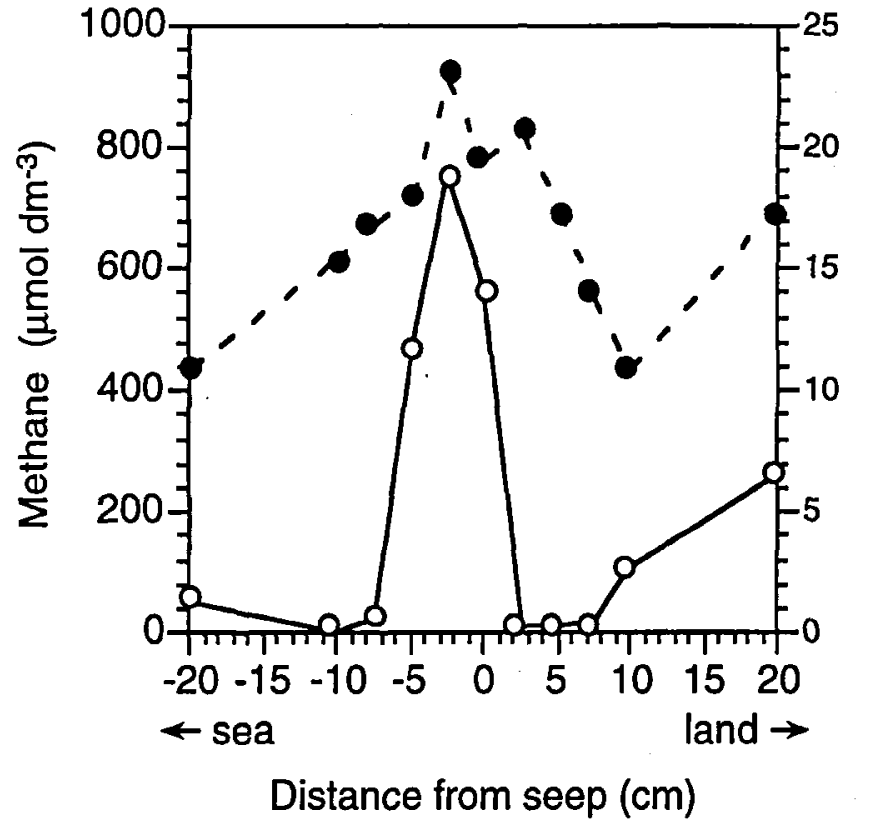

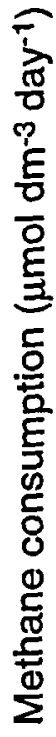

which E. litoralis was dominant. Adults of Oncholaimus brachycercus and juveniles of Viscosia cobbi constituted most of the omnivorous nematodes present. Predators accounted for more than half of the nematode biomass and omnivores constituted only $3 \%$ of the nematode fauna. Samples from the seeps contained a higher proportion, by biomass, of predators than elsewhere. This was due to the presence of many adults of $E$. brunetti, which

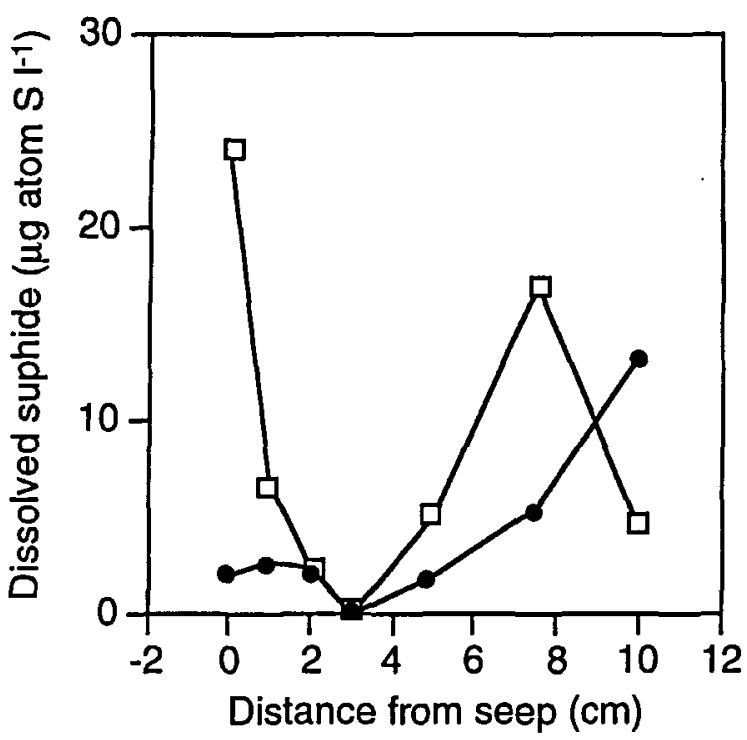

Fig. 10. Sulphide concentrations in the interstitial water at $2 \mathrm{~cm}$ - and $4 \mathrm{~cm} \square-\square$ depth along a transect through a seep. has an adult wet weight of $31-38 \mu \mathrm{g}$ in contrast to $<1 \mu \mathrm{g}$ for almost all other nematode species.

\section{Interstitial water flux around seeps}

Gas rising through the sediment carries with it a quantity of water. This is similar to the air-lift effect often used to circulate water from sub-bottom aquarium filters. The effect at the seeps was demonstrated by injecting a solution of dye into the sand $5 \mathrm{~cm}$ away from a seep, at a sediment depth of $5 \mathrm{~cm}$. The dye appeared in the fluid stream approximately 10 minutes later. Interstitial water is replaced by the overlying seawater drawn into the sediment around a seep. This effect is demonstrated (Fig. 8 ) by the redox profile taken along an east - west transect through seep 9 (Fig. 2). At the seep the rising gas carries with it some deep interstitial water to the surface and the Eh is low, below $-90 \mathrm{mV}$ throughout the sediment. $5 \mathrm{~cm}$ away from the seep conditions are considerably more oxic due to the draw-down of overlying water causing a sharp rise in the $\mathrm{Eh}$ of $>100 \mathrm{mV}$ throughout the $10 \mathrm{~cm}$ sediment depth studied. This water draw-down progressively decreases with increasing distance from the gas seep, as shown by the decreasing Eh, until at a distance beyond $50 \mathrm{~cm}$ the Eh rises again due to the influence of neighbouring seeps.

The methane content of the upper $4 \mathrm{~cm}$ of sediment surrounding a seep is shown in Fig. 9. Concentrations decrease rapidly with increasing distance from the seep and then increase again at $20 \mathrm{~cm}$ distance, probably due to neighbouring gas seeps. A down-beach flow of water is apparent from the asymmetric concentration profile 


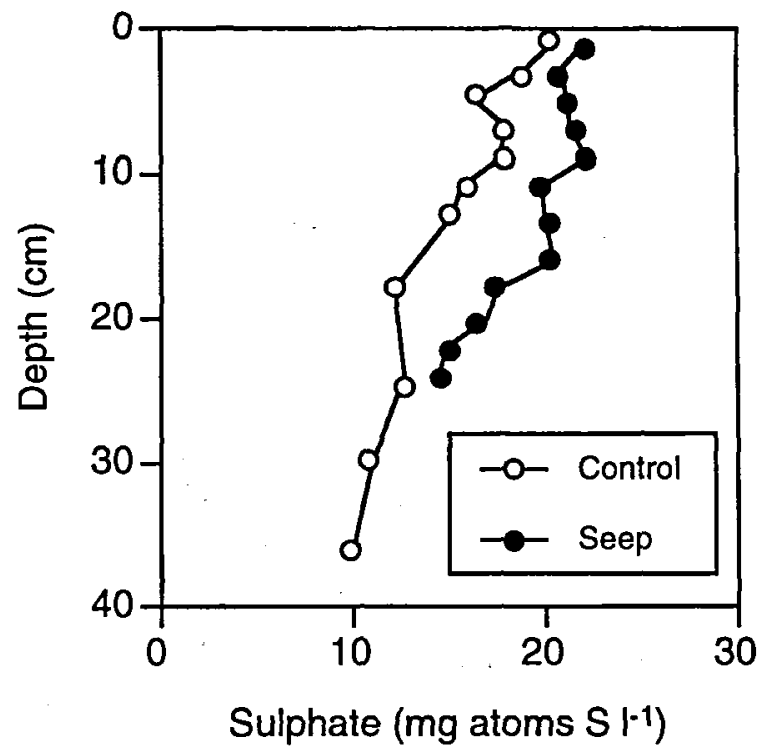

Fig. 11. Sulphate concentration profiles in the interstitial water in a sediment core taken over a seep and in one taken $30 \mathrm{~m}$ north of the highest part of the reef on 16.5.91.

around the seep. Fig. 9 also shows changes in the aerobic methane oxidation rate, which parallels the methane concentrations. The rate doubled in the immediate vicinity of the seep.

In shallow water the effect of the seeps is often demonstrated by the presence of a ring of black, iron sulphiderich sand on the surface surrounding the gas outlet. When interstitial sulphide is measured (Fig. 10) high dissolved sulphide concentrations are found at the seep but this sulphide is absent $2 \mathrm{~cm}$ away and then gradually increases in concentration with increasing distance from the seep. This mirrors the redox pattern.

A comparison of the sulphate profiles between two cores taken on the same day, one from directly over a seep and the other taken outside the seep area, $30 \mathrm{~m} \mathrm{~N}$ of the main rock, is shown in Fig. 11. The higher sulphate concentration in the seep core is believed to be due to the replenishment of sulphate in the sediment surrounding the seep by the overlying water being drawn down into the sediment.

Seep water, that is the water issuing from the seep together with the gas, was collected at seep 1 (Fig. 2) on 31.8.92. A sample of the surrounding seawater was collected at the same time and analysed together with the seep water. The seawater had a $\mathrm{pH}$ of 8.03 compared with a pH for the seep water of 7.72. Phosphate concentrations were $0.13 \mu \mathrm{M}$ in the seawater and $0.88 \mu \mathrm{M}$ in the seep water, whereas nitrite concentrations were higher in the seawater $\left(0.85 \mu \mathrm{g}_{\text {at }} \mathrm{N}^{-1}\right)$ than in the seep water $(0.65 \mu \mathrm{g}$ at $\mathrm{N}^{-1}$ ). The mean ammonia concentration in water issuing from this seep, when measured in March 1992, was $20.0 \mu \mathrm{g}$ at $\mathrm{N}^{-1}$ compared to $1 \mu \mathrm{g}$ at $\mathrm{N}^{-1}$ for the seawater. The effects on the pore water chemistry of the water circulation induced by the rising gas bubbles are illustrated diagramatically in Fig. 12.

Sulphate reduction, methane oxidation and bacterial numbers

Profiles of sulphate reduction rates were determined in 13 sediment cores. The peak rates were in the upper $10 \mathrm{~cm}$ of the sediment column. Fig. 13 shows the typical sulphate reduction profiles for a core taken over a seep and for a core taken north of the reef in May 1991. The sulphate reduction rates were integrated over the upper 20 $\mathrm{cm}$ of sediment. The measured rates were, with four exceptions, in the range 1.1 to $8.0 \mathrm{~m}$ moles sulphate reduced $\mathrm{m}^{-2}$ day $^{-1}$ (Fig. 14). There was no apparent trend in sulphate reduction rate between the cores taken over the seeps, those taken close to the seeps and cores taken away from the reef. The two highest rates, 54.4 and 101.9 $\mathrm{m}$ moles sulphate reduced $\mathrm{m}^{-2}$ day $^{-1}$, were from a large area of sand in which buried seaweed was decomposing $2-4 \mathrm{~cm}$ below the surface (Dando, Fenchel, Jensen, O'Hara, Niven \& Schuster, 1993b). Storms cause much Zostera and Laminaria to be detached and washed up on the beaches along this part of the coast. On occasion there was a layer of Laminaria up to $15 \mathrm{~cm}$ thick covering part of the study site. In addition the sand was often covered in May by sedimented phytoplankton, after blooms which had reduced the visibility in the inshore water to less than $10 \mathrm{~cm}$. Benthic diatoms would also contribute to the organic input. This high carbon input complicates analysis of the geochemistry at the site since there is considerable sulphide and methane production in the upper sediment as well as that contributed by the lower gas reservoirs.

Potential aerobic methane oxidation rates were determined in sediment suspensions containing a dissolved methane concentration of $1 \mu \mathrm{M}$. The potential integrated methane oxidation rates were measured in 6 cores collected in May 1991 (Fig. 14). Most of the cores had similar rates, $0.2-0.6 \mathrm{~m}$ moles methane consumed $\mathrm{m}^{-2}$ day $^{-1}$, although one seep core had a higher rate, $5.5 \mathrm{~m}$ moles methane consumed $\mathrm{m}^{-2} \mathrm{day}^{-1}$. The sediment aerobic methane oxidation rate profiles for the most active seep core and for a core taken north of the seepage area are shown in Fig. 13. In these, and the other cores studied, the aerobic methane oxidation was confined to the upper $9 \mathrm{~cm}$ of sediment, although in one core no oxidation could be detected below $4 \mathrm{~cm}$ depth. Oxygen will penetrate deep into the sand during periods of low water.

Total bacterial numbers in sediment profiles were determined for one seep and one control core. The distribution is shown in Fig. 15. There was no enhanced bacterial density in the seep core, indeed the bacterial counts decreased more rapidly in the seep core when compared to the control. 
Fig. 12. Diagram illustrating the bubble - generated interstitial water circulation.
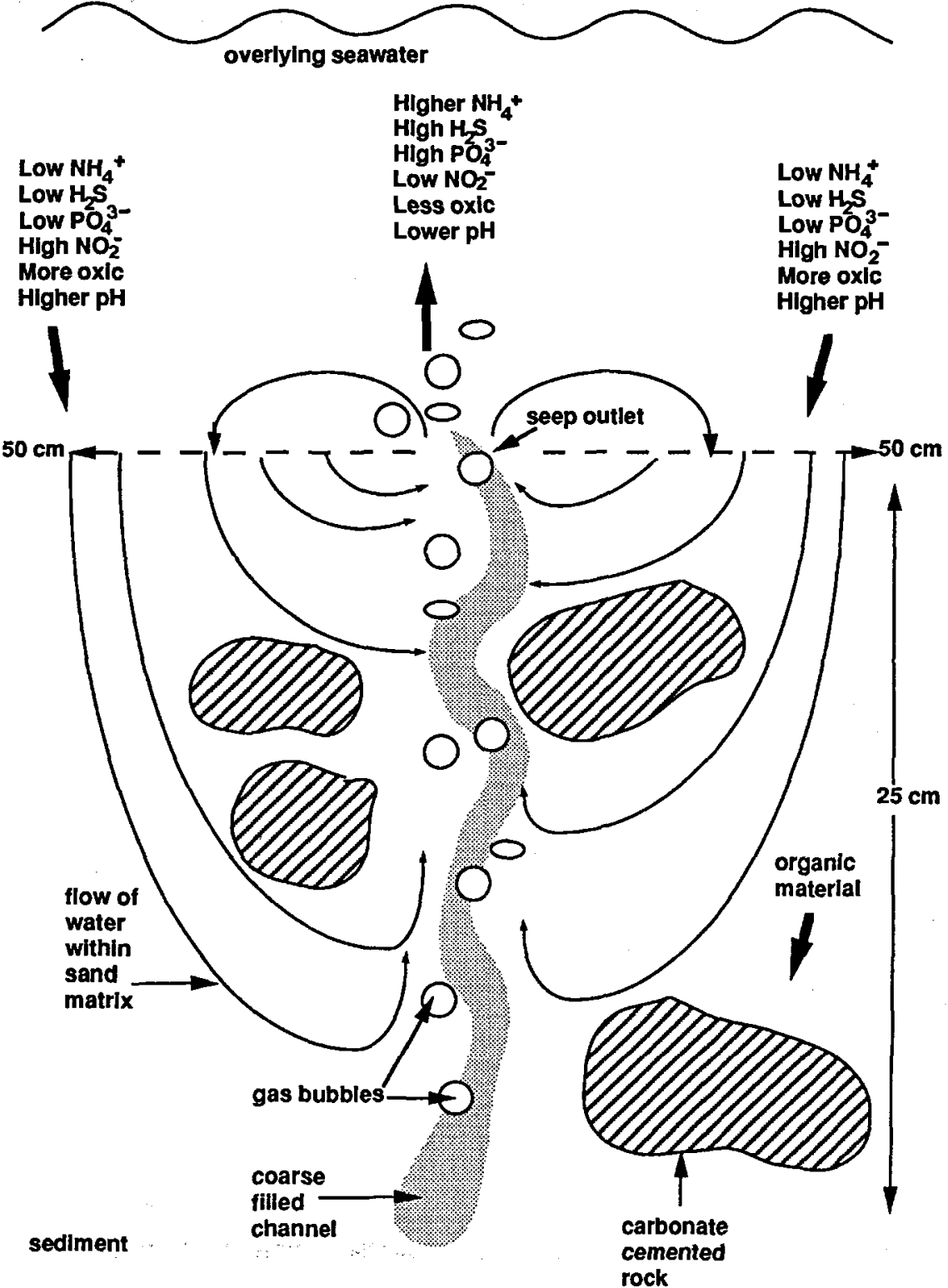

\section{Discussion}

The accessibility of the seep site at Bangsbostrand enabled detailed sampling of the gas and of the sediments to be carried out. It was possible to study the changes in the sediment surrounding the seeps on a scale of centimetres, compared to the less precise sampling possible at deeper sites (Dando et al., 1991; Jensen et al., 1992). This allowed a detailed study of the physical, chemical and biological processes associated with methane seepage through the sediment to be made. An outline of the results has been presented in this paper. More detailed results on the flow rates and isotope composition of the gas, in- terstitial water flow, microbial activity and the food chain will be published elsewhere.

The gas escaping at this site was $>91 \%$ methane, containing small amounts of carbon dioxide, $<1 \%$, and hydrogen sulphide, $<0.04 \%$. This agrees with the analysis of gas collected from deeper sites in the Kattegat and from onshore wells (Jørgensen et al., 1990; Laier et al., 1992). Hydrogen was almost completely absent, $<10 \mathrm{vpm}$, suggesting that an early report of $6 \%$ hydrogen in shallow gas from Vendsyssel (Dreyer Jørgensen, 1945) may have been an error. The frequent absence of hydrogen sulphide in seep gas and the large variations in the content of this gas between individual seeps suggests that the hydrogen 


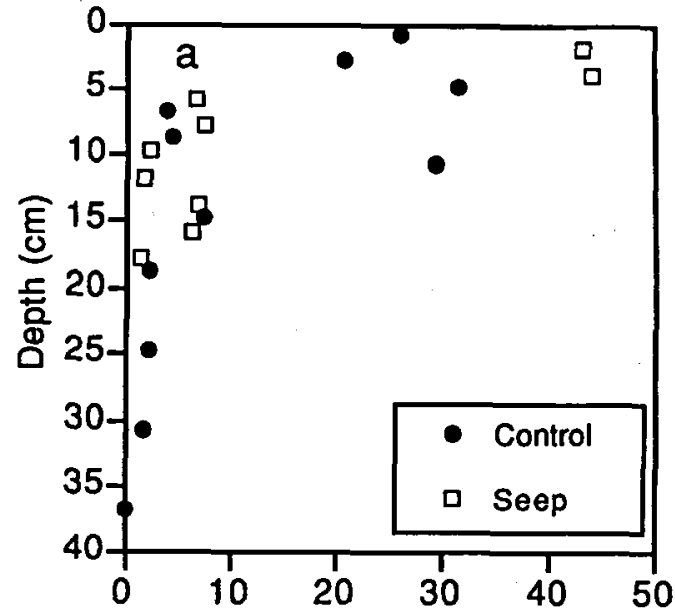

Sulphate reduction ( $\mu \mathrm{g}$ atoms $S \mathrm{dm}^{-3}$ day $^{-1}$ )

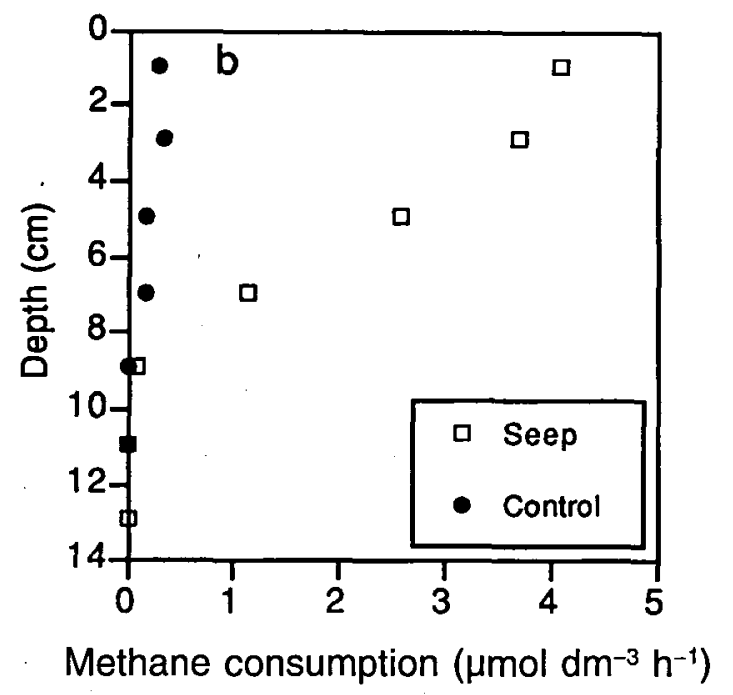

Fig. 13. a. sulphate reduction and b. methane oxidation profiles in a seep core and in a core taken $20 \mathrm{~m}$ north of the highest point on the reef on 14.5.91.

sulphide originates in the sediment around individual seeps rather than coming from a deeper reservoir. A patchiness in sulphate reduction rates would be expected due to burial of organic matter as a result of wave action and due to the draw down of both dissolved and fine particulate organic material by the bubble-generated circulation (Fig. 12).

Changes in the distribution of gas outlets over a period of time partly due to the changing depth and distribution of sand at the site following high water conditions and wave action. Water depth regulates the flow at some, but not all, seeps. It is possible that the degree of flow regulation may be dependent on the size and rigidity of the gas channel and grain size of the channel fill. The most active seep accounted for almost $20 \%$ of the total gas flow and showed no evidence of long-term change in flow rate. Similarly the total gas flow from the whole reef appears to be constant in the longer term. This suggests that seeps closing in one part of the area are replaced by new seeps starting up in other parts of the reef.

The passage of gas bubbles through the sediment to the
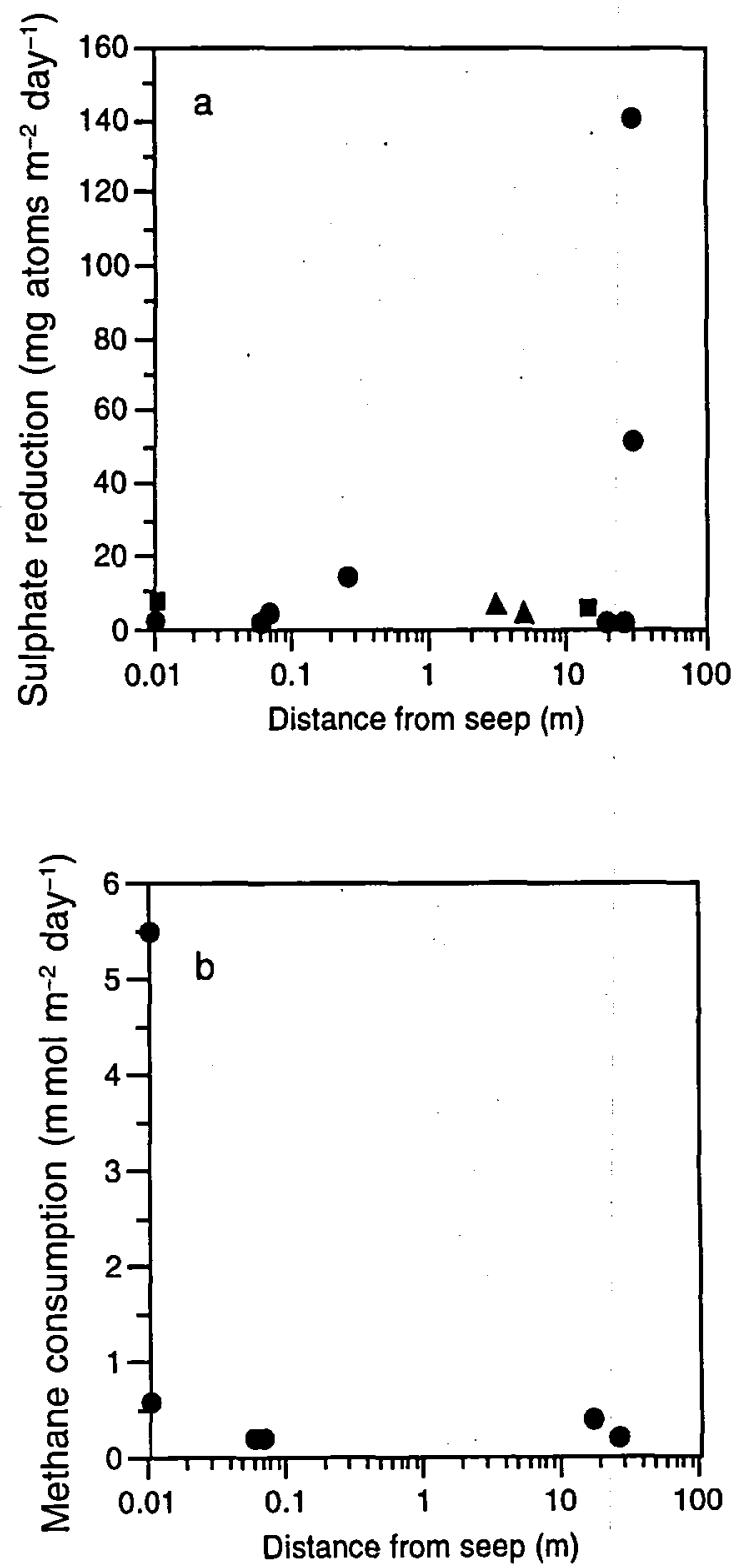

Fig. 14. a. integrated sulphate reduction rates and b. aerobic methane oxidation rates in cores taken at the site during, October 1990; , May 1991 and A, May 1992. 


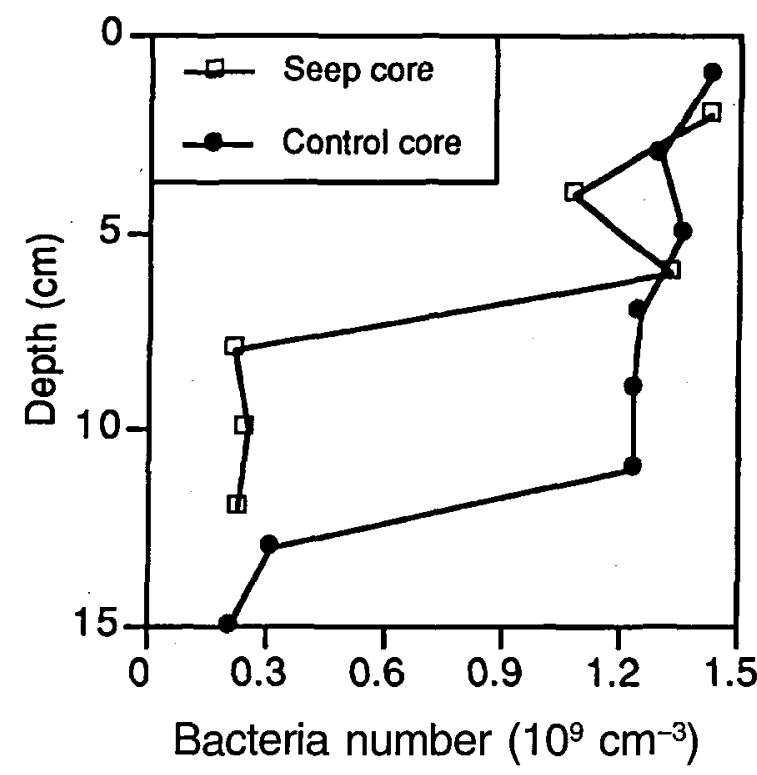

Fig. 15. Number of bacterial cells in a sediment core taken directly over a seep and in one taken $20 \mathrm{~m}$ north of the reef in May 1991.

surface generates an interstitial circulation (Fig. 12). Thus close to the gas outlet the sediment is actually less reduced than sediment at equivalent depths, away from the influence of the seeps (Fig. 8). We do not know how far this effect extends from the seeps. The studies reported here indicate that, for seeps with flow rates of 1-2 $1 \mathrm{~h}^{-1}$, this circulation extends at least $50 \mathrm{~cm}$ horizontally from the seep and the sulphate profile (Fig. 11) suggests that this circulation extends to a sediment depth of at least $25 \mathrm{~cm}$. This sub-surface circulation is the reason that methane and sulphide concentrations are low in the sediment in the immediate vicinity of the seeps.

The water pumped out of the sediment by the escaping gas is a mixture of the overlying seawater and the interstitial water. It is enriched in phosphate and ammonia and depleted in nitrite. These nutrients may be expected to stimulate algal production and help to account for the rich growth of Ulva, Monostroma, Cladophora and Enteromorpha seen on the reef sandstone.

High sulphide concentrations are associated with methane seeps (Dando et al., 1991; Dando \& Hovland, 1992). However, enhanced sulphate reduction rates were not found in the vicinity of seeps at the deeper, $10-12 \mathrm{~m}$, Kattegat sites (Jensen et al., 1992), nor in the seeping North Sea pockmark (Dando et al., 1991). The rates reported in this study were, with the exception of those from an area of marked organic deposition, similar to those reported from elsewhere in the Kattegat, $0.5-7.9 \mathrm{~m}$ moles sulphate reduced $\mathrm{m}^{-2}$ day $^{-1}$ (Jørgensen, 1989; Jørgensen, Bang \& Blackburn, 1990). This suggests that, at least at shallow methane seep sites, there is little stimulation of sulphate reduction by the escaping methane. The fastest gas seeps, which were presumably the least altered since leaving the upper reservoir, had little or no hydrogen sulphide. The observations on black sediment being pumped out with the gas at some of the shallow seeps are probably indicative of deep interstitial water, with a high dissolved sulphide concentration, being brought to the surface by the ascending gas. This sulphide reacts with the available iron in the upper sediment layers to form the conspicuous black ferrous sulphide deposits frequently observed around the gas outlets. During most of the study the shallow seeps were overlain by $20 \mathrm{~cm}$ or more of sediment, above the carbonate cementation, whereas the deeper seeps had the carbonate-cemented sandstone exposed on the seabed. The interstitial circulation, generated by the rising gas, would therefore readily draw sulphide in from the sulphate reduction zone maximum in the upper $10 \mathrm{~cm}$ of sediment to the shallow seeps. This could explain the higher hydrogen sulphide concentrations observed in the seep gas from the shallower sites (Fig. 6). The large daily differences observed in hydrogen sulphide content are probably due to the patchiness of organic burial, and hence sulphate reduction rates, combined with changes in the interstitial water circulation in response to wave driven differences in sediment size and distribution.

The reduction in macrofauna biomass in the seep area is probably not due to the hydrogen sulphide concentrations in the sediment, since these are variable and patchy across the site. A more likely cause is due to the restriction on burrowing due to the presence of the carbonate cemented sediment. The lugworm, Arenicola marina, was the major macrobenthic component of the infauna, in terms of biomass. This species was never found in sediment above the sandstone. Since it was frequently found at depths of $40 \mathrm{~cm}$ below the sediment surface at the control sites it is probable that it avoids burrowing in areas where it cannot reach this depth. The buried rock would also prevent infauna above the reef burrowing deeper to escape being washed away during storm conditions and this must also affect the macrofaunal composition of the site.

Intertidal sandflats are known to harbour a rich and diverse meiofauna (Higgins \& Thiel, 1988). However, with the exception of nematodes, there is almost a complete absence of meiobenthic organisms at this intertidal site. On the other hand, the dominant nematode species studied here are common inhabitants of intertidal-shallow subtidal sandy bottoms in Europe. The increased number of nematode species, abundance, biomass and depth penetration close to the seeps can be explained by the favourable interstitial conditions. These are a result of the draw-down of overlying oxygenated and organic-rich seawater (Fig. 12). The nematode biomass close to the seeps is of the same order of magnitude as the total macrobenthic biomass, i.e. a few grams wet weight $\mathrm{m}^{-2}$. In contrast, at the seeps, the small number of nematode species, their low abundance and limited depth penetration are ascribed to the prevailing anoxic conditions 
and to the winnowing effect of the bubble stream. $E$. brunettii, the largest of the nematode species at this site, was more dominant in these winnowed sediments than elsewhere on the intertidal flat.

The overall effect of gas seepage on the fauna at this intertidal / low subtidal site is similar to that described by Jensen et al. (1992) for the deeper Kattegat sites and more generally by Dando \& Hovland (1992). Sediment sorting due to gas efflux and rock formation by carbonate cementation produce conditions for hard bottom fauna to settle. The microbial methane oxidation does not, to judge from the absence of old carbon in animals around the seeps, provide the base for a productive food chain at the site. This result is similar to the situation described for gas seepage in the North Sea (Dando et al., 1991) and for the seeps at 10-12 $\mathrm{m}$ water depth in the Kattegat (Jensen et al., 1992).

\section{Acknowledgements}

We acknowledge the use of the facilities at the Havbiologisk Feltlaboratorium, University of Copenhagen, Fredrikshavn. This study was supported by the Institute of Petroleum, the Carlsberg Foundation, the German Research Council and the CEC (under MAST Contract 0044).

\section{Dansk sammendrag}

Det er tidligere påvist, at naturgas forekommer i marine kvartære aflejringer i Vendsyssel og i den nordlige del af Kattegat. Vi har kortlagt 65 gas-udsivninger i et område på $30 \mathrm{~m} \times 70 \mathrm{~m}$ langs den sydlige del af Bangsbo Strand syd for Frederikshavn, hvor der også forekommer methan-afledte sandstensformationer. Gassen består overvejende (91-100\%) af methan sammen med kuldioxid og svovlbrinte. Mængden af udstrømmende gas varierer fra udsivning til udsivning fra mindre end $1 \mathrm{l} \mathrm{pr}$. time og op til 211 pr. time, mens den totale mængde udslupne gas i området synes at være ret konstant, $1101 \mathrm{pr}$. time.

Vi har undersøgt effekten af den udstrømmende gas på porevandskemiske faktorer og plante- og dyrelivet i området. Den udstrømmende gas trækker porevand med op. Dette inducerer en cirkulation af porevand $i$ interstitierne, idet iltmattet havvand bliver suget ned $\mathrm{i}$ bunden $\mathrm{i}$ en afstand op til $50 \mathrm{~cm}$ fra en gas-udsivning. Inde i området med gas-udsivning varierer sulfatreduktionsraterne mellem 1.1-17.1 m mol sulfat reduceret pr. $\mathrm{m}^{2}$ pr. dag, og de aerobe methan oxidationsrater varierer mellem $0.2-5.5 \mathrm{~m}$ mol methan konsumeret pr. $\mathrm{m}^{2} \mathrm{pr}$. dag. Det med gassen udstrømmende vand har en for $ø$ get koncentration af fosfat og ammonium. Der var færre dyrearter og mindre biomasse ved gas-udsivningerne end udenfor området. I overensstemmelse med porevandscirkulationen i området med gas-udsivningerne trenger faunaen dybere ned $\mathrm{i}$ havbunden omkring gas-udsivningerne end ved selve gas-udsivningerne. ${ }^{14} \mathrm{C}$ målinger af dyrevæv viser, at kun lidt methan indgår $i$ en fødekæde.

\section{References}

Cline, J. D. 1969: Spectrophotometric determination of hydrogen sulphide in natural waters. Limnol. Oceanogr. 14, 454 458.

Dal Pont, G., Hogan, M. \& Newell, B. 1974: Laboratory techniques in marine chemistry. II. Determination of ammonia in seawater and the preservation of samples for nitrate analysis. Report of the Division of Fisheries and Oceanography, no. 55, CSIRO, Australia.

Dando, P. R., Austen, M. C., Burke, R. J., Kendall, M. A., Kennicutt, M. C., Judd, A. G., Moore, D. C., O'Hara, S. C. M., Schmaljohann, R. \& Southward, A. J. 1991: Ecology of a North Sea pockmark with an active methane seep. Mar. Ecol. Prog. Ser. 70: 49-63.

Dando, P. R. \& Hovland, M. 1992: Environmental effects of submarine seeping natural gas. Cont. Shelf Res. 12, 11971207.

Dando, P. R., O'Hara, S. C. M., Schuster, U., Taylor, L. J., Clayton, C. J., Baylis, S. \& Laier, T. 1993a: Gas seepage from a carbonate-cemented sandstone reef on the Kattegat coast of Denmark. Mar. Petroleum. Geol. (in press)

Dando, P. R., Fenchel, T., Jensen, P., O'Hara, S. C. M., Niven, S. J. \& Schuster, U. 1993b: The ecology of gassy, organic rich sediment in a shallow subtidal area on the Kattegat coast of Denmark. Mar. Ecol. Prog. Ser. 100: 265-271.

Dreyer Jørgensen, K. 1945: Frederikshavn-Strandby gasomraadets geologi. Naturens Verden 29, 11-32.

Grasshof, K., Ehrhardt, M. \& Kremling, K. 1983: Methods of seawater analysis., 2 nd. edition, Verlag Chemie, Weinheim. $417 \mathrm{pp}$.

Higgins, R. P. \& Thiel, H., 1988: Introduction to the study of meiofauna. Smithsonian Institutional Press, Washington, D.C. $488 \mathrm{pp}$.

Hovland, M. \& Thomsen, E., 1989: Hydrocarbon-based communities in the North Sea? Sarsia 74, 29-42.

Jensen, P. 1982: A new meiofauna sample splitter. Ann. zool. fenn. 19, 233-236.

Jensen, P. 1983: Meiofaunal abundance and vertical zonation in a sublittoral soft bottom, with a test of the Haps corer. Mar. Biol. 74, 319-326.

Jensen, P. 1987: Feeding ecology of free-living aquatic nematodes. Mar. Ecol. Prog. Ser. 35, 187-196.

Jensen, P., Aagaard, I., Burke, R. A., Dando, P. R., Jørgensen, N. O., Kuijpers, A., Laier, T., O'Hara, S. C. M. \& Schmaljohann, R. 1992: "Bubbling reefs" in the Kattegat: submarine landscapes of carbonate-cemented rocks support a diverse ecosystem at methane seeps. Mar. Ecol. Prog. Ser. 83, 103-112.

Jessen, A. 1936: Vendsyssels Geologi. Danmarks Geologiske Undersøgelse V (2) $195 \mathrm{pp}$.

Jørgensen, B. B. 1978: A comparison of methods for the quantification of bacterial sulphate reduction in coastal marine sediments. 1. Measurements with radiotracer techniques. Geomicrobiology J. 1: 11-27.

Jørgensen, B. B. 1989: Sulphate reduction in marine sediments from the Baltic Sea - North Sea transition. Ophelia 31, 1-15.

Jørgensen, B. B., Bang, M. \& Blackburn, T. H. 1990: Anaerobic mineralization in sediments from the Baltic Sea - North sea transition. Mar. Ecol. Prog. Ser. 59, 39-54.

Jørgensen, N. O. 1976: Recent high magnesium calcite/aragonite cementation of beach and submarine sediments from Denmark. J. Sediment. Petrology 46, 940-951.

Jørgensen, N. O. 1992: Methane-derived carbonate cementation of marine sediments from the Kattegat, Denmark: geochemical and geological evidence. Mar. Geol. 103, 1-13.

Jørgensen, N. O., Laier, T., Buchardt, B. \& Cederberg, T. 1990: 
Shallow hydrocarbon gas in the northern Jutland-Kattegat region, Denmark. Bull. geol. Soc., Denmark 38, 69-76.

Laier, T., Jørgensen, N. O., Buchardt, B., Cederberg, T. \& Kuijpers, A. 1992: Accumulation and seepages of biogenic gas in Northern Denmark. Cont. Shelf. Res. 12, 1173-1186.

Meyer-Reil, L.-A. 1983: Benthic response to sedimentation events during autumn to spring at a shallow water station in the Western Baltic. II. Analysis of benthic bacterial populations. Mar. Biol. 77, 247-256.
Newton, G. L., Dorian, R. \& Fahey, R. C. 1981: Analysis of biological thiols: derivatization with monobromobimane and separation by reverse-phase high performance liquid chromatography. Anal. Biochem. 114, 383-387.

Zhabina, N. N. \& Volkov, I. I. 1978: A method of determination of various sulphur compounds in sea sediments and rocks. In: Krumbein, W.E. (ed.). Environmental Biogeochemistry and Geomicrobiology, Vol. 3, Methods, metals and assessment. Ann. Arbor Science Publishers, Ann Arbor, 735-746. 